\title{
Emotional Intelligence and Spiritual Well-Being as Predictors of Physical Health among Adults
}

\author{
Masaud Ansari ${ }^{1 *}$
}

\section{ABSTRACT}

An attempt was made to study the influence of emotional intelligence and spiritual well being on physical health among adults. Sample of the study consisted of 250 male participants only. The sample was selected through incidental sampling technique, from Aligarh district. Emotional Intelligence scale Developed and standardized by Singh (2004), Spiritual well being scale developed by Paloutzian and Ellison (1982) and Physical Health scale developed by Mohammadyfar, et al. (2009) were used for the data collection. The data were analyzed, and Pearson's correlation was applied to study the relationship between different dimensions of emotional intelligence and physical health as well as relationship between spiritual well being's dimensions and physical health. Further, Multiple regression (stepwise) was administered to examine the impact of emotional intelligence and spiritual well being on physical health. The findings were showed that the all dimensions of emotional intelligence i.e. Self-Awareness, Selfregulation, Motivation, Social Awareness and Social Skills are positively and significantly correlated with physical health. The findings also reveal that different dimensions of spiritual well being i.e. existential well being and religious well being are positively and significantly correlated with physical health. Finally, it was found that emotional intelligence and spiritual well being had there major impact on physical health among adults.

Keywords: Emotional intelligence, Spiritual Well being, Physical Health and -being and Adults.

As per the present study is concerned, adults were selected for the sample. This is stage of an Individual's life, when he/she has to play several responsibilities and a number of comprehensive decisions an individual has to make about life events. During the decision making he has to consider other's feelings as well as rights. Where, emotional intelligence is required to deal with these sensitive situations. A person, who is spiritual can make better decision as compare to nonspiritual because spiritual may have spiritual values like Accountability, Commitment, Compassion, Connectedness, Cooperation, Courage, Creativity, Credibility, Enrichment, Flexibility, Honesty, Innovation, Integrity, Justice, Mortality, Patience, Respect, Responsibility, Sense of duty, Sincerity and tolerance. There is a third variable physical health, the researcher was curious to know that what extent emotional intelligence and spiritual well being influence it,

\footnotetext{
${ }^{1}$ Research Scholar, Department of Psychology, Aligarh Muslim University, Aligarh *Corresponding Author

(C) 2015 I M Ansari; licensee IJIP. This is an Open Access Research distributed under the terms of the Creative Commons Attribution License (http://creativecommons.org/licenses/by/2.0), which permits unrestricted use, distribution, and reproduction in any Medium, provided the original work is properly cited.
} 


\section{Emotional Intelligence and Spiritual Well-Being as Predictors of Physical Health among Adults}

if yes then either positive or negative. Adults were selected for the study, because this is the stage where people get mature and proceed towards the spiritual well being.

\section{Emotional Intelligence}

Today, the most acceptable definition for emotional intelligence (EI), has been provided by Salovey and Mayer (1990) who are conceived as the 'fathers' of the construct, since they first introduced the term 'emotional intelligence'. According to them, EI is 'a type of emotional information processing that includes accurate appraisal of emotions in oneself and others, appropriate expression of emotion, and adaptive regulation of emotion in such a way as to enhance living'.

More recently, they modify the above definition (Mayer, Caruso, \& Salovey, 1999) and conceptualized EI as 'an ability to recognize the meanings of emotions and their relationships, and to reason and problem-solve on the basis of them. Emotional intelligence involved in the capacity to perceive emotions, assimilate emotion-related feelings, understand the information of those emotions, and manages them.'

\section{Spiritual Well Being}

The origin of word spirituality is from the Latin word 'spiritus', meaning "breath" or "life" (Elkins, 1999).

Gomez and Fisher (2003) defined spiritual wellbeing as “A state of being, reflecting positive feelings, behaviors, and cognitions of relationships with oneself, others, the transcendent and nature, that in turn provide the individual with a sense of identity, wholeness, satisfaction, joy, contentment, beauty, love, respect, positive attitudes, inner peace and harmony, and purpose and direction in life, (p. 1976).”

\section{Physical Health}

Huber, et al., (2011) defined that "health is the level of functional or metabolic efficiency of a living organism. In humans it is the ability of individuals or communities to adapt and selfmanage when facing physical, mental or social challenges.

The World Health Organization (WHO, 2006) defined health in its broader sense in its 1948 constitution as "a state of complete physical, mental, and social well-being and not merely the absence of disease or infirmity."

\section{REVIEW OF LITERATURE}

Spirituality is a determinant of better mental health because it can serve as a source of hope and strength in times of crises (Koenig, McCullough, \& Larson, 2001). Whereas Ansari and Khan (2015) in a research paper entitled "Role of Mental Health on Well-Being among Post Graduate Students” (forth coming...) found that mental health plays an important role in the overall well being in general, and particularly for physical health. Spiritual well-being is an essential part of 


\section{Emotional Intelligence and Spiritual Well-Being as Predictors of Physical Health among Adults}

mental, emotional and physical health. It is considered to be a primary coping resource on the journey of recovery and healing. This healing takes place in drug treatment centers, eating disorder residential programs and at trauma recovery (Casa Palmera Staff, 2012). Each person's spirituality is greatly impacted by the community they are a part of and the relationships they take part in. Spiritual well-being is not a practice of isolation but rather of affecting and involving the people around us as our own perspective is formed. Spiritual well-being groups and sessions provide an open and safe environment to explore, learn, practice, support and heal. This safe-haven offered in such a group is important to those attending a drug and alcohol rehab center or for those in trauma therapy. Spiritual well-being programs often include group exploration and experiential practices on the topics of meditation, prayer, forgiveness, personal values, purpose in life, the role of self-esteem in spiritual connection, healthy relationships, and developing an authentic relationship with a Higher Power, God, or Spiritual Dimension (Casa Palmera Staff, 2012). In general, spiritual well-being as outlined in the three points serves to enhance any religious beliefs or affiliations. In fact, religion can be viewed as a form of spiritual practice (Casa Palmera Staff, 2012).

\section{Three Areas of Life Experience}

Spiritual well-being is rooted in three primary areas of life experience. These are:

- Relationships (including self-esteem, healthy connection to others and an authentic connection to a Higher Power, God or Spiritual Dimension)

- Personal Values

- Purpose in Life

The degree of one's spiritual well-being can be witnessed in the health of each of the above areas. Dedicating time to explore and develop this aspect of well-being is essential to making it a powerful resource on the healing journey (Casa Palmera Staff, 2012).

\section{Benefits of Spiritual Well-Being (Casa Palmera Staff, 2012)}

A few of the numerous benefits of spiritual well-being include:

- Feeling content with your life's situation

- Making time to spend alone and find inner peace

- Taking time to reflect and resolve life's issues

- Finding satisfaction in a job well done

- Taking part in an active lifestyle rather than merely standing by and watching life as it passes

- Maintaining balance and control of life

- Building relationships

- Feeling purpose and meaning in life

- Accepting and growing from the challenges of life

The nursing diagnosis readiness for enhanced spiritual well-being is defined as an "ability to experience and integrate meaning and purpose in life through a person's connectedness with self, 


\section{Emotional Intelligence and Spiritual Well-Being as Predictors of Physical Health among Adults}

others art, music, literature, nature, or a power greater than oneself." (Anonymous, 2002, p. 68) and was approved by NANDA in 2002.

A person with this diagnosis may:

- Having an enhanced desire for hope

- Feel that there is meaning and purpose to their life;

- Have a sense of peace or serenity;

- Surrender love;

- Be forgiving towards them self, and request forgiveness of others;

- Request forgiveness from others;

- Have a satisfying philosophy of life;

- Experience joy, courage, or heightened coping;

- Pray or meditate;

- Connect with others;

- Provide service to others;

- Experience connections with nature;

- Experience connections with or a desire to create art, music, or literature, particularly of a religious or spiritual nature;

- Experience a connection with a power greater than oneself;

- Report mystical experiences; or

- Participate in religious activities.

Rinju George, Baby Shari (2012) conducted a study dividing a group into two section and found that low emotional intelligence group was high in stress and high emotional intelligence group had low stress. Annamaria (2012) found that people who are more emotionally intelligent feel healthier than those who are less emotionally intelligent. They also found that emotional intelligence significantly impacts both physical health and subjective wellbeing. A nationally representative sample of 1310 adults was recruited by a governmental health insurance service in Belgium. Participants filled in measures of Emotional Intelligence (EI), emotions, social support, health behaviors like smoking, drinking, eating habits and exercises. Results showed that EI was a significant predictor of health indicators. Even more interesting, emotional intelligence predicted most health indicators better than did already known predictors such as social support or health related behaviors (Mikolajczak, 2013). Schutte et al. (2007) also used this approach to examine the relationship between EI and health, an area that had not received specific attention in the previous meta-analytic studies. Their undertaking showed that higher EI is linked with better health. Natalio et al. (2006) found positive relationships between emotional intelligence and mental, social, and physical health. With the research of Harold Koenig (2001) and others, the interplay between our physical selves and our spiritual selves is being recognized. Research points to persons having greater health, longevity, even faster healing, if they participate in activities that support their spirit and not merely their bodies. 


\section{OBJECTIVES}

- To study the relationship between different dimensions of emotional intelligence and Physical health.

- To study the relationship between different dimensions of spiritual well being and Physical health.

- To examine the impact of emotional intelligence and spiritual well being on physical health among adults.

\section{Hypotheses}

- There will be a positive and significant relationship between different dimensions of emotional intelligence and Physical health.

- There will be a positive and significant relationship between different dimensions of spiritual well being and Physical health.

- There will be significant impact of emotional intelligence and spiritual well being on physical health among adults.

\section{METHODLOGY}

\section{Sample}

Participants of the study consisted of 250 male respondents only. The sample was selected through incidental sampling technique, from Aligarh district. The age range was 20 to 45.

\section{Measures}

\section{Emotional Intelligence Scale (EIS)}

Developed and standardized by Singh (2004) consists of 60 statements. These 60 statements were grouped into fine dimensions i.e.: Self Awareness, Self Regulation, Motivation, Social Awareness, and Social Skills. Higher score indicates high level of emotional intelligence in that respective area. The five areas of emotional intelligence scale contain same numbers of items which are mentioned as Self Awareness 12 items, Self Regulation 12 items, Motivation 12 items, Social Awareness 12 items and Social Skills 12 items. The scores range from 12 to 60 for each area and 60 to 300 for the whole scale, higher the scores is the indicator of high emotional intelligence and lower the scores low emotional intelligence. Cronbach's Alpha reliability of this scale is 0.70 .

\section{Spiritual Well-Being Scale}

The Spiritual Well-Being Scale (SWB) Scale, developed by Paloutzian and Ellison (1982), measures religious well-being (RWB), which is the individual's beliefs and relationship with God, and existential well-being (EWB), which is the individual's sense of meaning and purpose in life. Each of these 2 subscales contains 10 items, individually measured on a 6-point Likert scale, ranging from "strongly agree" to "strongly disagree" without a midpoint. Eleven of the items are worded to control for response-set bias. The items are scored from 1 to 6 , with 6 indicating a greater well-being. Possible subscale scores range from 10 to 60; possible SWB scores range from 20 to 120 . 
Test-retest reliability is 0.88 to 0.99 for religious well being (RWB), 0.73 to 0.98 for Existential well being (EWB), and 0.82 to 0.99 for overall spiritual well being (SWB). The internal consistency reliability coefficients range from 0.82 to 0.94 for RWB, 0.78 to 0.86 for EWB, and 0.89 to 0.94 for SWB.

\section{Physical Health Scale}

This scale was developed as a physical check list by Mohammadyfar et al., (2009), lower scores on the measure of physical-ill health has been supposed to indicate higher physical health. They considered the opinion of experts as a content validity and criterion validity was also examined by correlation of the scores of mental health. Significant positive correlation is proved the criterion validity of check list. The Cronbach's Alpha Coefficient was reported 0.7151, and testretest reliability with 3 weeks interval was 0.856 . Then there is acceptable level of internal consistency. Internal reliability of 0.76 was reported. For the analytical convenience the items are scored reversed, and then the higher score shows better physical health and low score indicates worse physical health.

\section{Procedure}

The respondents were approached individually and before administering the questionnaires good rapport established. Afterward they were asked to read the instructions carefully and give their responses to complete the questionnaire of emotional intelligence, spiritual well being and physical health. Participants were taken 25 to 45 minutes to give there complete responses. All the respondents were told that their anonymity will be preserved and their responses will be confidential. Finally, with special thanks questionnaires were collected from them and scored manually.

\section{Statistical Analysis}

In order to meet the research objectives data was analyzed; Pearson's correlation was administered to study the relationship between different dimensions of emotional intelligence and different dimensions of spiritual well being with physical health. Further, multiple regression was computed to examine the influence of emotional intelligence and spiritual well being on physical health among adults.

\section{RESULTS}

Table- 1: shows correlation between Physical Health and different dimensions of Emotional Intelligence among adults.

\begin{tabular}{|l|l|l|l|l|l|l|}
\hline \multicolumn{2}{|c|}{} & $\begin{array}{l}\text { Self } \\
\text { Awareness }\end{array}$ & $\begin{array}{l}\text { Self } \\
\text { Regulation }\end{array}$ & Motivation & $\begin{array}{l}\text { Social } \\
\text { Awareness }\end{array}$ & $\begin{array}{l}\text { Social } \\
\text { Skills }\end{array}$ \\
\hline $\begin{array}{l}\text { Physical } \\
\text { Health }\end{array}$ & $\begin{array}{l}\text { Pearson } \\
\text { Correlation }\end{array}$ & $.744^{* *}$ & $.786^{* *}$ & $.741^{* *}$ & $.638^{* *}$ & $.845^{* *}$ \\
\cline { 2 - 7 } & Sig. (2-tailed) & .000 & .000 & .000 & .000 & .000 \\
\cline { 2 - 7 } & $\mathrm{N}$ & 250 & 250 & 250 & 250 & 250 \\
\hline
\end{tabular}


Table 1 show that Physical health in adults positively and significantly correlated with self Awareness $(R=.744, p=000)$, Self Regulation $(R=.786, p=000)$, Motivation $(R=.741, p=000)$, Social Awareness $(\mathrm{R}=.638, \mathrm{p}=000)$, Social Skills $(\mathrm{R}=.845, \mathrm{p}=000)$.

Table- 2: shows correlation between Physical Health and different dimensions of Spiritual Well-being among adults.

\begin{tabular}{|l|l|l|}
\hline \multicolumn{2}{|c|}{ Correlations } \\
\hline \multirow{2}{*}{ Existential Well Being } & \multicolumn{1}{|c|}{} & Physical Health \\
\hline & Pearson Correlation & $.746^{* *}$ \\
\cline { 2 - 3 } & Sig. (2-tailed) & .000 \\
\cline { 2 - 3 } & $\mathrm{N}$ & 250 \\
\hline Religious Well Being & Pearson Correlation & $.711^{* *}$ \\
\cline { 2 - 3 } & Sig. (2-tailed) & .000 \\
\cline { 2 - 3 } & $\mathrm{N}$ & 250 \\
\hline
\end{tabular}

**. Correlation is significant at the 0.01 level (2-tailed).

Table 2 show that Physical health in adults positively and significantly correlated with Existential well Being $(\mathrm{R}=.746, \mathrm{p}=000)$ and Religious well being $(\mathrm{R}=.711, \mathrm{p}=000)$.

Table- 3: shows summary of multiple regressions for "physical health" of adults.

\begin{tabular}{|c|c|c|c|c|c|c|}
\hline Variables & $\mathbf{R}$ & $\begin{array}{l}\text { Adjusted } \\
\text { R Square }\end{array}$ & $\mathbf{F}$ & $\begin{array}{l}\text { Level of } \\
\text { Significance }\end{array}$ & $\begin{array}{l}\text { Standardized } \\
\text { Coefficients }\end{array}$ & $\mathbf{t}$ \\
\hline & & & & & Beta & \\
\hline $\begin{array}{l}\text { Emotional } \\
\text { Intelligence }\end{array}$ & \multirow[t]{2}{*}{.988} & \multirow[t]{2}{*}{.976} & \multirow[t]{2}{*}{5.030} & \multirow[t]{2}{*}{.000} & .656 & 65.505 \\
\hline $\begin{array}{l}\text { Spiritual } \\
\text { Well being }\end{array}$ & & & & & .628 & 62.662 \\
\hline
\end{tabular}

It can be seen from table 3, the adjusted $\mathrm{R}$ square value is .976 which indicates that this model accounts for $97.6 \%$ of the variance in the "physical health" of adults. The level of significance is at .000 levels which show that it is highly significant. The Beta value of Emotional intelligence is .656 and significance level is .000 which states that the variable contribute significantly in the physical health. The Beta value of Spiritual well being is .628 and the significant level is .000, which also shows that it has an important impact on the "physical health" out of these two predictor variables, Emotional intelligence contribute highly to the adult's physical health as compared to Spiritual well being. 


\section{DISCUSSION}

Different dimensions of emotional intelligence i.e. Self Awareness, Self Regulation, Motivation, Social Awareness and Social Skills are positively and significantly correlated with the physical health of adults. As we know that Self-awareness is the ability of introspection and the capability to recognize oneself as an individual separate from the environment and other human being it is also aware individual for care themselves. Several emotional conditions are intensified by selfawareness. However, some people may seek to increase their self-awareness by realizing and communicating with others. People are found to be more likely to align their behavior with their standards when become self-aware. People will be negatively affected if they do not live up to their personal standards. A variety of environmental cues and situations encourage awareness of the self, such as mirrors, an audience, or being recorded. These cues also increase accuracy of one-self (Thomas, 2001). The development of self-awareness makes the people conscious about their wellness, either related to physical mental, social, emotional, or spiritual well being.

Self-regulation is an ability to control one's emotions, behavior, and desires in the face of external demands in order to function in society (Matt, 2014). By self regulation an individual can escape himself from the bad activities like alcohol abuse etc. which is an indicator of better physical health. Timpano state that self-control is essential in behavior to achieve goals as well as to avoid impulses and emotions that could prove to be negative (Timpano et al., 2013). Intrinsic motivation is the self-desire to seek out new things and new challenges, to analyze one's capacity, to observe and to gain knowledge. It is driven by an interest or enjoyment in the task itself, and exists within the individual rather than relying on external pressures or a desire for reward (Ryan et al., 2000) whereas, Extrinsic motivation refers to the performance of an activity in order to attain a desired. Finding shows that motivational dimension of emotional well being is highly correlated in a positive direction with physical health. It is also suggested by Ryan, (2000) that intrinsic motivation is a natural motivational tendency and is a critical element in cognitive, social, and physical development. Social skill is anyskill facilitating interaction and communication with others. Social rules and relations are created, communicated, and changed in verbal and nonverbal ways. The process of learning such skills is called socialization. According to Karl Marx (Questia, 2014), human beings enter into certain productive, or economic, relations and these relations lead to a form of social consciousness.

The researcher found that spiritual well being significantly correlated with physical health with its both dimensions i.e. existential well being and religious well being. This finding supported by Casa Palmera staff (2012), they state that spiritual well-being is an essential part of mental, emotional and physical health. It is considered to be a primary coping resource on the journey of recovery and healing. The significant impact of emotional intelligence and spiritual well being was found on health of adults which comprise the social awareness and social skills etc. As, social factors (support) played a major role in human life to tackle with critical circumstances. Each person's spirituality is greatly impacted by the community they are a part of and the relationships they take part in. Spiritual well-being is not a practice of isolation but rather of 


\section{Emotional Intelligence and Spiritual Well-Being as Predictors of Physical Health among Adults}

affecting and involving the people around us as our own perspective is formed. Spiritual wellbeing groups and sessions provide an open and safe environment to explore, learn, practice, support and heal. This safe-haven offered in such a group is important to those attending a drug and alcohol rehab center or for those in trauma therapy (Casa Palmera Staff1, 2012).

Spirituality is a determinant of better mental health because it can serve as a source of hope and strength in times of crises (Koenig, McCullough, \& Larson, 2001). Whereas Ansari and Khan (2015) in a research paper entitled "Role of Mental Health on Well-Being among Post Graduate Students" (forth coming...) found that mental health plays an important role in the overall well being in general, and particularly for physical health. It is also found that the both dimensions of spiritual well-being i.e. existential and religious well being positively and significantly contribute to the adult's physical health. Following the benifites of spiritual well being that is taking part in an active lifestyle rather than merely standing by and watching life as it passes, maintaining balance and control of life, building relationships and feeling purpose and meaning in life leads an individual toward better life experiences (Casa Palmera Staff, 2012).

\section{CONCLUSION}

Finally, it is concluded that emotional intelligence and spiritual well being including its different dimensions positively and highly correlated with adult's physical health. It means that when emotional intelligence and spiritual well being will increase physical health also increase and when emotional intelligence and spiritual well being will decrease physical health also decrease.

It is found that emotional intelligence has significant impact on physical health among adults. It means that those who has high emotional intelligence will be healthier as compare to those who has low emotional intelligence. Because several studies showed that self awareness leads an individual to maintain them-self, self regulation develops the sense of control, motivation prompts to achieve the specific as well as general goals of the life, due to social awareness a person participate in several social activities, and social skill helps to deal with crucial circumstances and better communication. These all are preceding factors of better physical health.

It is also found that spiritual well being has significant contribution to physical health of adults. There are some spiritual values which give a right direction to an individual to live a happy and peaceful life: e.g. Accountability, Autonomy, Commitment, Compassion, Connectedness, Cooperation, Courage, Creativity, Credibility, Energy, Enrichment, Flexibility, Honesty, Innovation, Integrity, Justice, Knowledge, Mortality, Patience, Quality, Respect, Responsibility, and Sense of duty, Sincerity and tolerance. If any person will adopt and follow these values to deal with his/her life then it is expected that his/her life will awesome, and he/she will experience life satisfaction. 


\section{REFERENCES}

Anonymous (2002). Diagnosis Review Committee: New and revised diagnoses. Nursing Diagnosis 13(2) p. 68-71. Philadelphia:NANDA

Ansari M. and Khan S. A. (2015), "Role of Mental Health on Well-Being among Post Graduate Students” (forth coming...) Aligarh Muslim University, Aligarh, U.P. India

Casa Palmera Staff ${ }^{1}$ Posted on Monday, September $17^{\text {th }}$, 2012, 14750 El Camino Real Del Mar, CA $92014+1$ 858-481-4411 casapalmera.com, Addiction Treatment Center, https://casapalmera.com/spiritual-well-being

Casa Palmera Staff ${ }^{1}$ Posted on Monday, September $17^{\text {th }}$, 2012, 14750 El Camino Real Del Mar, CA $92014+1$ 858-481-4411 casapalmera.com, Addiction Treatment Center, https://casapalmera.com/spiritual-well-being

Casa Palmera Staff ${ }^{2}$ Posted on Monday, September 17th, 2012, 14750 El Camino Real Del Mar, CA $92014+1$ 858-481-4411 casapalmera.com, Addiction Treatment Center, https://casapalmera.com/spiritual-well-being

Casa Palmera Staff ${ }^{3}$ Posted on Monday, September 17th, 2012, 14750 El Camino Real Del Mar, CA $92014+1$ 858-481-4411 casapalmera.com, Addiction Treatment Center, https://casapalmera.com/spiritual-well-being

Casa Palmera Staff ${ }^{4}$ Posted on Monday, September 17th, 2012, 14750 El Camino Real Del Mar, CA $92014+1$ 858-481-4411 casapalmera.com, Addiction Treatment Center, https://casapalmera.com/spiritual-well-being

Casa Palmera Staff ${ }^{5}$ Posted on Monday, September 17th, 2012, 14750 El Camino Real Del Mar, CA $92014+1$ 858-481-4411 casapalmera.com, Addiction Treatment Center, https://casapalmera.com/spiritual-well-being

Casa Palmera Staff ${ }^{6}$ Posted on Monday, September 17th, 2012, 14750 El Camino Real Del Mar, CA $92014+1$ 858-481-4411 casapalmera.com, Addiction Treatment Center, https://casapalmera.com/spiritual-well-being

Casa Palmera Staff ${ }^{7}$ Posted on Monday, September 17th, 2012, 14750 El Camino Real Del Mar, CA $92014+1$ 858-481-4411 casapalmera.com, Addiction Treatment Center, https://casapalmera.com/spiritual-well-being

Elkins, D. N. (1999). Spirituality. Psychology Today, 32, 44-47.

Gomez, R., \& Fisher, J. W. (2003). Domains of spiritual well-being and development and validation of the spiritual well-being questionnaire. Personality and Individual Differences, 35, 1975-1991. http://dx.doi.org/10.1016/S0191-8869(03)00045-X

Huber M, Knottnerus JA, Green, L., van der Horst H, Jadad AR, Kromhout D, Smid H. BMJ 2011; 343 (d4163) http://savenhshomeopathy.org/wp-content/uploads/2012 /09/HuberDefinition-Health-BMJ-21.pdf

Koenig, Harold G. et. al. (2001) Handbook of Religion and Health, Oxford University Press

Matt DeLisi. "Chapter 10: Low Self-Control Is a Brain-Based Disorder". SAGE Publications Ltd. Retrieved 4 May 2014.

Mikolajczak M., Université catholique de Louvain, Belgium, http://dx.doi.org/ 10.1016/j.paid.2013.07.404

Natalio Extremera and Pablo Fernández-Berrocal (2006), Universidad de Málaga, The Spanish Journal of Psychology Copyright 2006 by The Spanish Journal of Psychology 2006, Vol. 9, No. 1, 45-51 ISSN 1138-7416 


\section{Emotional Intelligence and Spiritual Well-Being as Predictors of Physical Health among Adults}

Paloutzian, R. F.,\& Ellison, C.W. (1982). Loneliness, spiritual well-being, and quality of life. In L. A. Peplau \& D. Perlman (Eds.), Loneliness: A sourcebook of current theory, research and therapy. New York: Wiley.

Ref. Mohammadyfar M. A., Khan M. S., and Kord Tamini B. (2009), The Effect Of Emotional Intelligence And Job Burnout On Mental And Physical Health. Journal of the Indian Academy of Applied Psychology, 35(2), 219-226.

Reuven Bar-On (2012). The Impact of Emotional Intelligence on Health and Wellbeing, Emotional Intelligence - New Perspectives and Applications, Prof. Annamaria Di Fabio (Ed.), ISBN: 978-953-307-838-0, book edited by Annamaria Di Fabio, ISBN 978-953307-838-0, Published: February 1, 2012 under CC BY 3.0 license. InTech, Available from: $\quad$ http://www.intechopen.com/books/emotional-intelligence-new-perspectivesandapplications/the-impact-of-emotional-intelligence-on-health-and-wellbeing

Rinju George, Baby Shari (2012), IJPSS Volume 2, Issue 9 ISSN: 2249-5894

Rochat, Philippe (2003). "Five levels of self-awareness as they unfold early in life".Consciousness and Cognition 12 (4): 717-731. doi:10.1016/s1053-8100(03)000813.

Ryan, R. M.; Deci, E. L. (2000). "Self-determination theory and the facilitation of intrinsic motivation, social development, and well-being". American Psychologist 55 (1): 6878.doi:10.1037/0003-066X.55.1.68.

Ryan, Richard; Edward L. Deci (2000). "Intrinsic and Extrinsic Motivations: Classic Definitions and New Directions". Contemporary Educational Psychology 25 (1): 5467.doi:10.1006/ceps.1999.1020.

Salovey, P., \& Mayer, J.D. (1990). Emotional intelligence, Imagination, Cognition and Personality, 9, 185-211.

Salovey, P., Bedell, B.T., Detweiler, J.B., \& Mayer, J.D. (1999). Coping intelligently: Emotional intelligence and the coping process. In C.R. Snyder (Ed.), Coping: The psychology of what works (pp. 141-164). New York: Oxford Psychology Press.

Schutte, N. S., Malouff, J. M., Thorsteinsson, E. B., Bhullar, N. Rooke, S. E. (2007). A metaanalytic investigation of the relationship between emotional intelligence and health Personality and Individual Differences, 42(6), 921-933.

Singh, S. (2004). Development of measure ofemotional intelligence. Psychological studies, 49, 136-141.

Social Consciousness Questia, 2014. Retrieved 27 May 2014. It is a general consensus that those who get social support has better health and communication skill as compare to those who live alone.

Thomas S. Duval Self-Awareness and Causal Attribution, p. 1, Springer, 2001 ISBN 978-07923-7501-2

Timpano, K. R.; Schmidt, N. B. (2013). "The relationship between self control deficits and hoarding: A multi method investigation across three samples". The Journal of Abnormal Psychology 122 (1): 13-25. doi:10.1037/a0029760.

World Health Organization. Constitution of the World Health Organization - Basic Documents, Forty-fifth edition, Supplement, October 2006.

World Health Organization. Constitution of the World Health Organization - Basic Documents, Forty-fifth edition, Supplement, October 2006. 